\title{
Cooperação internacional em matéria de lavagem de dinheiro: da importância do auxílio direto, dos tratados internacionais e os mecanismos de prevenção
}

\author{
International cooperation on money laundering: \\ the importance of direct assistance, international \\ treaties and prevention mechanisms
}

\section{Anna Carolina Canestraro ${ }^{1}$}

Universidade de Coimbra - Portugal carolina.canestraro@gmail.com

http://lattes.cnpq.br/1604392529884511

http://orcid.org/0000-0002-3534-4589

Resumo: O presente estudo tem por objetivo trazer uma possível resposta às dificuldades que o contexto da criminalidade global trouxe para a persecução do crime de lavagem de dinheiro em razão de um cada vez mais deficiente controle sobre os fluxos financeiros, em especial no âmbito internacional. Isto é, haveria algum mecanismo à disposição do Estado que o permitiria realizar com mais eficiência e rapidez esse necessário follow the money típico dessa específica criminalidade? Como uma possível resposta elegeu-se aqui a Cooperação Internacional como

1 Mestre em Ciências Jurídico-Criminais pela Faculdade de Direito da Universidade de Coimbra. Especialista em Direito Penal Econômico e Teoria do Delito pela Universidad de Castilla-La Mancha. Especialista em Compliance e Direito Penal pelo Instituto de Direito Penal Econômico e Europeu (IDPEE) da Faculdade de Direito da Universidade de Coimbra. Pós-Graduada em Direito Processual Penal pelo Instituto de Direito Penal Econômico e Europeu (IDPEE), em parceria com o Instituto Brasileiro de Ciências Criminais (IBCCRIM). Graduada em Direito pela Faculdade de Direito da Universidade Presbiteriana Mackenzie. Pesquisadora financiada pelo programa "ERASMUS+" na Georg-August-Universität Göttingen. 
um importante instrumento de persecução ao crime de lavagem de dinheiro; e, com fundamento nas recomendações do Grupo de Ação Financeira (GAFI), ressalta-se, dentre os mecanismos de cooperação, o auxílio direto como um eficaz e célere mecanismo para acompanhar a dinamicidade que exige a persecução desse crime. $\mathrm{E}$, ao fim, destaca-se a importância da união desses mecanismos de cooperação a métodos preventivos, tais como as Unidades de Inteligência Financeira, para um eficiente combate à essa nova criminalidade.

Palavras-chave: Cooperação Internacional; Lavagem de dinheiro; Carta Rogatória; Auxílio Direto; Unidade de Inteligência Financeira.

ABSTRACT: The present study aims to provide a possible response to the difficulties that the context of global crime has brought to the prosecution of money laundering in reason of an increasingly reduced control over financial flows, especially at an international level. In other words, would there be any mechanism at the disposal of the State that would allow it to do the necessary follow-the-money typical of this specific crime more efficiently and quickly? As a possible answer, the international cooperation was chosen as an important instrument of prosecution for the crime of money laundering. And based on the recommendations of Financial Action Task Force (FATF), among all the mechanisms of cooperation, direct assistance was prioritized as the most effective and swift mechanism to accompany the dynamics that demand the pursuit of this crime. In the end, is demonstrated the importance of combining mechanisms of cooperation with preventive methods, with emphasis on the Financial Intelligence Units, in order to efficiently combat this new crime.

KEYwoRDs: International Cooperation; Money Laudering; Letters Rogatory; Direct Assistance; Financial Intelligence Unit.

SUMÁRIO: Introdução; 1 . Considerações sobre o crime de lavagem de dinheiro no âmbito de uma criminalidade global; 2. Da cooperação jurídica internacional; 2.1 Previsões internacionais; 2.2 Mecanismos judiciais de cooperação; 3. Da transmissão do pedido de auxílio mútuo; 3.1 Carta Rogatória; 3.2 Auxílio direito; 4. Grupo Egmont e Unidades de Inteligência Financeira; Considerações Finais; Referências. 


\section{INTRODUÇÃO}

A questão que se pretende abordar com o presente trabalho diz respeito a como realizar o combate - abrangendo-se aqui tanto a persecução como a prevenção - do crime de lavagem de dinheiro frente ao fenômeno da criminalidade globalizada, contexto este que permite a troca de informações e, principalmente, o fluxo de capitais de modo quase instantâneo de uma forma cada vez menos controlada. Isto é, como poderia o Estado realizar a persecução dessa criminalidade de um modo mais eficiente e compatível com esse novo e interligado contexto econômico?

Em razão da necessidade de combate dessa avançada criminalidade, a comunidade jurídica vem buscando trazer ao longo dos últimos anos as mais diversas respostas, dentre elas, por exemplo, vem se ocupando intensamente a ciência jurídico-penal da responsabilidade penal da pessoa jurídica e dos denominados programas de compliance ${ }^{2}$. No entanto, a despeito da importância de tais institutos, busca-se com o presente trabalho chamar atenção para uma terceira possível resposta, a cooperação internacional. E isto pois, uma vez que esta criminalidade se verifica cada vez mais organizada e internacionalizada, não seria inevitável a necessidade de um aprofundamento de uma cooperação a nível internacional como forma de tornar mais eficaz o seu combate? Ou seja, facilitando assim a colaboração e a troca de informações entre as autoridades competentes entre os diferentes Estados e sistemas financeiros interessados ${ }^{3}$ ?

E para que se possa demonstrar a importância da Cooperação Internacional no combate ao crime de lavagem de dinheiro, pretendese fazer, a início, e mediante uma análise doutrinária e jurisprudencial, especialmente europeia, uma abordagem sobre a criminalidade global, bem como sobre o conceito e as características do crime de lavagem de dinheiro, destacando-se sua internacionalização. Na sequência,

2 Nesse sentido: NIETO MARTÍN, Adán. La responsabilidad penal de las personas jurídicas: esquema de un modelo de responsabilidad penal. Nueva Doctrina Penal, Buenos Aires, A, p. 125-159, 2008.

3 BUCHO et. al. apud SIMÕES, Euclides Dâmaso. A importância da cooperação judiciária internacional no combate ao branqueamento de capitais. Revista Portuguesa de Ciência Criminal, Coimbra, v. 16, n. 3, p. 423-474, jul./set, 2006. p.423. 
busca-se trazer a cooperação internacional propriamente dita, bem como as convenções e recomendações internacionais que se verificaram importantes ao longo do presente estudo para alcançar as conclusões apresentadas. Ao fim, objetiva-se abordar os mecanismos judiciais de cooperação com fundamento nas orientações do grupo especializado GAFI (Grupo de Ação Financeira), destacando-se, ao final, a importância dos acordos internacionais e a sua necessária e importante comunicação com métodos preventivos ${ }^{4}$.

\section{Considerações sobre o crime de lavagem de dinheiro NO ÂMBITO DE UMA CRIMINALIDADE GLOBAL}

A necessidade de expansão das economias e o aprimoramento das facilidades de meios de comunicação à distância determinaram o chamado fenômeno da globalização ${ }^{5}$; fenômeno este que, por sua vez, é caracterizado pela troca instantânea de informações, conhecimentos tecnológicos e, principalmente, de fluxos financeiros. No entanto, tal dinamicidade, aliada ao progresso dos meios informáticos, trouxe repercussões não apenas a nível dos procedimentos lícitos, mas também a nível de práticas criminosas ${ }^{6}$, permitindo-se a construção do denominado "mercado global do crime"

A globalização e a integração econômica, então, acarretaram em uma delinquência contra os interesses financeiros, gerando uma

4 Vale a ressalva de que apesar de o artigo se utilizar amplamente de doutrina europeia, não serão aqui esmiuçadas as particularidades da cooperação dentro exclusivamente daquele que se pretende intitular espaço de liberdade, segurança e justiça europeu. E isto pois esta cooperação se vê regulada por um regime completamente diferente e específico; regime este que, para ser abordado corretamente, deveria ser objeto de estudo de toda uma nova pesquisa e, portanto, em razão do recorte temático, não será aqui abordado.

5 SIMÕES, Euclides Dâmaso. A importância da cooperação judiciária internacional no combate ao branqueamento de capitais. Revista Portuguesa de Ciência Criminal, Coimbra, v. 16, n. 3, p. 423-474, jul./set, 2006. p.423.

6 Idem.

7 PRADO, Luiz Regis. O novo tratamento penal da lavagem de Dinheiro (Lei 12.683/2012). Revista dos Tribunais Online, v. 201, n. 926, p. 401- 436, dez. /2012. p.402. 
nova concepção de delito que, desta vez, se centra em elementos como organização, transnacionalidade e poder econômico ${ }^{8}$. De fato, esse novo contexto favorece a ocorrência de atos delinquentes que acabam por se aproveitar desse espaço mundial de zonas de livre comércio e da ausência de barreiras fronteiriças para cometer e ocultar seus atos ilícitos.

Vista como uma criminalidade de players poderosos, a criminalidade global é também caracterizada pela magnitude de seus efeitos, normalmente econômicos ${ }^{9}$, sendo a sua persecução fundamental para a proteção da administração da justiça ${ }^{10}$ e prevenção da constituição de "paraísos jurídico-penais" ${ }^{11}$.

As práticas criminosas adquiriram então uma nova capacidade de organização e estruturação, ampliando-se para diferentes ramos de atividades como o tráfico de drogas, de pessoas, de armas, e, como "complemento natural dessas atividades", a lavagem de dinheiro ${ }^{12}$. Destarte, o crime de lavagem de dinheiro encontra-se intrinsicamente vinculado

8 Assim, SILVA SANCHEZ, Jesús-María. La Expanción del Derecho Penal: aspectos de la política criminal en las sociedades postindustriales. Madrid: Civitas Ediciones, 2001. p. 86.

9 SILVA SANCHEZ, Jesús-María. La Expanción del Derecho Penal: aspectos de la política criminal en las sociedades postindustriales. Madrid: Civitas Ediciones, 2001. p.87.

10 Não nos foge o conhecimento de que há uma importante discussão doutrinária a respeito de qual seria o bem jurídico tutelado nos casos desses crimes econômicos e, em especial, o crime de lavagem de dinheiro. No entanto, por questão de recorte temático, entenderemos nesse estudo que o bem jurídico tutelado seria a Administração da Justiça. Nesse mesmo sentido: BITENCOURT, Cezar Roberto; MONTEIRO, Luciana de Oliveira. Lavagem de dinheiro segundo a legislação atual. Revista Brasileira de Ciências Criminais, São Paulo, v. 21, n. 102, p. 163-220, mai./jun, 2013 e RODRIGUES, Anabela Miranda. Lavagem de capitais. São Paulo: IBCCRIM - Instituto Brasileiro de Ciências Criminais, 2014. (VIII Curso de Pós-graduação em Direito Penal Econômico). Disponível em: <http://www.ibccrim.org.br/tvibccrim_video/ 155-Lavagem-de-capitais>. Acesso em: 1 de maio de 2017.

11 SILVA SANCHEZ, Jesús-María. La Expanción del Derecho Penal: aspectos de la política criminal em las sociedades postindustriales. Madrid: Civitas Ediciones, 2001. p. 88.

12 RODRIGUES, Anabela Miranda. Globalização, Democracia e Crime. In: COSTA, José de Faria; SILVA, Marco Antonio Marques da. Direito penal especial, processo penal e direitos fundamentais: visão luso-brasileira. São Paulo: Quartier Latin do Brasil, 2006. p. 277- 310. p. 284. 
a esse contexto de criminalidade global e, justamente, se utiliza da dinamicidade e afrouxamento dos controles sobre o sistema financeiro para dissimular as origens de valores obtidos ilicitamente.

Também denominado branqueamento de capitais (Portugal e Espanha ${ }^{13}$ ), o delito traz um conceito praticamente produzido pela comunidade internacional e tem sua ideologia norteada fundamentalmente pelos interesses norte-americanos ${ }^{14}$.

Nos dizeres de Badaró e Bottini, o branqueamento de capitais pode ser definido como

$\mathrm{O}$ ato ou a sequência de atos praticados com a finalidade de mascarar a natureza, origem, localização, disposição, movimentação ou propriedade de bens, valores e direitos de origem delitiva ou contravencional, com o escopo último de reinseri-los na economia formal com aparência de licitude ${ }^{15}$

Podendo ser conduzido mediante o auxílio de bancos, instituições financeiras de caráter bancário, entidades não-financeiras ou mesmo

13 Com a ressalva de que há autores, tal como Abel Souto, que preferem o termo "blanqueo de dinero" e não "branqueamento de capitais", e isto pois, segundo ele "la locución 'blanqueo de dinero' presenta la ventaja de no ser un antitético híbrido de imprecisión y exactitud, es decir, que no supone un contraste entre el laxismo técnico jurídico que entraña el primer término y la precisión que se pretende con el segundo, lo que sí puede afirmarse tanto del "blanqueo de bienes" como del "blanqueo de capitales"; vide: ABEL SOUTO, Miguel Ángel. Normativa internacional sobre el blanqueo de dinero y su recepción en el ordenamiento penal español. Tese (Doutorado em 2001) - Universidad de Santiago de Compostela, Santiago de Compostela, 2001. p.69. Disponível em: <http://www.cervantesvirtual.com/nd/ark:/59851/bmc0p0z9>. Acesso em: 26 de maio de 2017.

14 Assim, Pieth "sobre todo por iniciativa de los EE.UU. nuevos documentos de la ONU comenzaron a abordar la temática del blanqueo de dinero"; PIETH apud ABEL SOUTO, Miguel Ángel, op.cit., loc. cit. No mesmo sentido, Lampe afirma que a Convenção das Nações Unidas de 1988 "se inspira manifiestamente en el $\S 1956$ del 18 U.S.C. introducido en 1986 en EE.UU”. LAMPE, Ernst- Joachim. El nuevo tipo penal del blanqueo de dinero ( $\$ 261$ StGB). Tradução de Miguel Abel Souto. Estudios Penales y Criminológicos, n ${ }^{\mathrm{XX}}$, 1997. p.118. nota 24.

BADARÓ, Gustavo Henrique; BOTTINI, Pierpaolo Cruz. Lavagem de dinheiro: aspectos penais e processuais penais: comentários à Lei 9.613/1998, com a alteração da Lei 12.863/2012. São Paulo: Editora Revista dos Tribunais, 2016. p.29. 
mediante o uso desses três órgãos sob um único "esquema" ${ }^{\text {, }}$ o crime de lavagem, muito relacionado com a criminalidade organizada, apesar de poder ser considerado autônomo ${ }^{17}$, tem como necessária a prática de uma infração penal que lhe seja antecedente.

Apesar de, originariamente, o crime antecedente ter sido vinculado com o tráfico de drogas, atualmente no Brasil os crimes antecedentes podem ser qualquer infração penal, abrangendo-se, portanto, crime ou contravenção penal; na União Europeia, por sua vez, os crimes antecedentes estão vinculados a uma definição de infrações graves ${ }^{18}$. E apesar de intimamente vinculado, há quem defenda sua autonomia perante o crime antecedente uma vez que a finalidade da incriminação aqui seria realizar o confisco dos valores alcançados ilicitamente, não guardando, portanto, necessária relação com o bem jurídico tutelado no crime anterior ${ }^{19}$.

Há de se chamar atenção para o fato de que as organizações criminosas não se limitam a uma só atividade delitiva, mas sim diversificam "seu ramo de atividades" a fim de aumentar sua rentabilidade ${ }^{20}$ e possibilitar o reinvestimento em suas estruturas e na prática de outras condutas

16 BLANCO CORDERO, Isidoro. El delito de blanqueo de capitales. Navarra: Editorial Aranzadi, 2002. p.63.

17 CALLEGARI, André Luis; WEBER, Ariel Barazzetti. Lavagem de Dinheiro. São Paulo: Atlas, 2014. p. 71.

18 Entendidas como "infrações puníveis com uma pena privativa de liberdade ou com uma medida de segurança de uma duração máxima superior a um ano ou, nos Estados cujo sistema jurídico preveja sanções com um limite mínimo, as infrações puníveis com uma pena privativa da liberdade ou uma medida de segurança de uma duração mínima superior a seis meses”, vide: CAEIRO, Pedro. A decisão-quadro do conselho, de 26 de Junho de 2001, e a relação entre a punição do branqueamento e o facto precedente: necessidade e oportunidade de uma reforma legislativa. In: ANDRADE, Manuel da Costa; COSTA, José de Faria; RODRIGUES, Anabela Miranda; ANTUNES, Maria João (eds.). Liber Discipulorum para Jorge de Figueiredo Dias. Coimbra: Coimbra Editora, 2003. p. 1067-1132. p. 1069.

19 Assim: RODRIGUES, Anabela Maria Pinto Miranda. Lavagem de capitais. São Paulo: IBCCRIM - Instituto Brasileiro de Ciências Criminais, 2014. (VIII Curso de Pós-graduação em Direito Penal Econômico). Disponível em: <http:// www.ibccrim.org.br/tvibccrim_video/155-Lavagem-de-capitais>. Acesso em: 1 de maio de 2017.

20 Nesse sentido: BLANCO CORDERO, Isidoro. El delito de blanqueo de capitales. Navarra: Editorial Aranzadi, 2002. p. 31. 
delitivas. Inclusive nesse sentido é, desde o atentado de 11 de setembro, a grande preocupação das Nações Unidas e também da União Europeia, em impedir que a lavagem de dinheiro financie novos atos de terrorismo ${ }^{21}$.

Quanto à execução propriamente dita, de acordo com a classificação do Grupo de Ação Financeira (GAFI) ${ }^{22}$, esta é composta por três fases - sendo comum, na prática, a sobreposição entre elas $^{23}$-, quais sejam:

(1) Ocultação/colocação (placement): momento em que o branqueador/lavador introduz seus proventos ilegais no sistema financeiro- é também a fase em que o agente se encontra mais vulnerável, pois o dinheiro ainda está integralmente vinculado com a sua origem ilícita e, assim, de mais fácil detecção ${ }^{24}$;

21 Havia inclusive, uma proposta de Diretiva do Parlamento Europeu e do Conselho justamente neste sentido (expirada em 23 de outubro de 2018) - Texto disponível em: <http://eur-lex.europa.eu/legal-content/PT/TXT/?uri=CELEX:52016PC0826>. Acesso em 22 de março de 2019.

FATF-GAFI. Le blanchiment de capitaux: qu'est-ce que c'est? - Comment blanchit-on des capitaux?. Disponível em: <http://www.fatf-gafi.org/fr/foireauxquestionsfaq/blanchimentdecapitaux/>. Acesso em: 29 de agosto de 2018. No mesmo sentido: CALLEGARI, André Luis; WEBER, Ariel Barazzetti. ,op. cit.,p.11 e ss. Para estudo de outras classificações, dentre elas a do Suíço Paolo Bernasconi, considerado "o pai da normativa penal relativa ao branqueamento de capitais”, vide: BLANCO CORDERO, Isidoro. El delito de blanqueo de capitales. Navarra: Editorial Aranzadi, 2002. p. 55 e ss.

23 Vale dizer que a Legislação Brasileira não exige, para a tipicidade da lavagem de dinheiro, que o ciclo se complete, ou seja, basta a consumação da primeira fase, a ocultação, para a materialidade delitiva; vide: BADARÓ, Gustavo Henrique; BOTTINI, Pierpaolo Cruz. Lavagem de dinheiro: aspectos penais e processuais penais: comentários à Lei 9.613/1998, com as alteração da Lei 12.863/2012. São Paulo: Editora Revista dos Tribunais, 2016. p. 32-33.

MACHADO, Leonardo Marcondes. A lavagem de dinheiro no Brasil: breves apontamentos sobre as gerações legislativas. Revista Síntese de Direito Penal e Processual Penal (continuação da Revista IOB de Direito Penal e Processual Penal), v.15, n. 90, p.34-43, fev./mar, 2015. p. 37. Disponível em <https:// bdjur.tjdft.jus.br/xmlui/handle/tjdft/27671>. Acesso em 26 de maio de 2018. Para uma análise mais aprofundada dos mecanismos de colocação, vide: BLANCO CORDERO, Isidoro. El delito de blanqueo de capitales. Navarra: Editorial Aranzadi, 2002. p. 65-69; CALLEGARI, André Luis; WEBER, Ariel Barazzetti. Lavagem de Dinheiro. São Paulo: Atlas, 2014. p. 12-23; MAIA, Rodolfo Tigre. Lavagem de Dinheiro (Lavagem de ativos provenientes de crime): anotações às disposições criminais da Lei n.9.613/98. São Paulo: Malheiros Editores, 2004. p.37-38. 
(2) Confusão/dissimulação (layering): representa a diluição do dinheiro inserido no mercado pela etapa anterior em incontáveis estratos, disseminados por meio de várias e sucessivas transações financeiras, no país de origem e no exterior, podendo se utilizar de uma multiplicidade de contas bancárias, estruturas societárias e regimes jurídicos variados ${ }^{25}$;

(3) Integração (integration): momento final do crime, que se verifica quando os valores já circulam dentro do mercado financeiro com aparência de legalidade.

Dentre as características do branqueamento de capitais, segundo Blanco Cordero, estão a globalização das atividades, em razão especialmente de sua internacionalização, a tendência ao profissionalismo ${ }^{26}$ e a complexidade dos novos métodos empregados ${ }^{27}$.

Quanto ao caráter internacional, embora no Brasil essa característica não seja tão visível em decorrência do tamanho geográfico do país, na Europa ela é fundamental. E isto pois, se o produto do crime ficasse adstrito ao sistema financeiro interno, haveria maior chance de o infrator ser detectado e os valores confiscados; assim, essencial a utilização do mercado internacional para que se consiga de fato dissimular a origem desses valores ${ }^{28}$ - aproveitando-se, muitas vezes, justamente dos problemas decorrentes da cooperação judiciária internacional e

25 MAIA, Rodolfo Tigre. Lavagem de Dinheiro (Lavagem de ativos provenientes de crime): anotações às disposições criminais da Lei n.9.613/98. São Paulo: Malheiros Editores, 2004. p. 70-71.

26 Havendo uma cada vez maior complexidade estrutural, inclusive com seções especializadas para lidar com o branqueamento, vide: SAVONA, Ernesto. Mafia money-laundering versus Italian legislation. European Journal on Criminal Policy and Research, v. 1-3, p. 31-56, 1993. p. 35. https://doi.org/10.1007/ BF02249506.

27 BLANCO CORDERO, Isidoro. El delito de blanqueo de capitales. Navarra: Editorial Aranzadi, 2002. p. 51.

28 Neste sentido: NETTO, Alamiro Velludo Salvador; COSTA, Helena Regina Lobo da. Lavagem de dinheiro: anteprojeto de Lei IBCCRIM. São Paulo: IBCCRIM - Instituto Brasileiro de Ciências Criminais, 2013. 2 v. (Seminário internacional do Instituto Brasileiro de Ciências Criminais, 19). Disponível em: <http://www.ibccrim.org.br/tvibccrim_video/243-Lavagem-de-dinheiro-anteprojeto-de-lei-IBCCRIM>. Acesso em: 1 de maio de 2017. 
intercâmbio de informações entre países com diferentes regulamentações, sistemas e culturas ${ }^{29}$.

Avultando esse viés internacional e transfronteiriço do crime de branqueamento, Christoph K. Greber faz distinção entre aqueles que seriam os "países do comportamento"30 - Länder der Handels; onde ocorreria o crime antecedente - e aqueles onde ocorreria o branqueamento propriamente dito - Länder der Geldwäscherei - no entanto, diante da dificuldade de atribuir certos estados a um dos dois termos, esta seria uma distinção bastante questionável ${ }^{31}$.

Ainda assim, há de se destacar que há locais, como a Suíça, por exemplo, que se destacam como países atraentes para o branqueamento justamente em razão das excelentes redes de comunicação e transportes, posição geográfica, falta de barreiras monetárias e cambiais e, principalmente, em decorrência do nível de proteção concedido ao sigilo bancário ${ }^{32}$.

Chama-se atenção também para as vantagens que derivam das entidades bancárias dos paraísos fiscais, que, em razão de sua nula ou mínima regulação e falta de interesse em especificar as origens dos bens em operação, permitem abertura de contas secretas e não-numeradas e constituição de empresas com titulares anônimos que operam livres de impostos ${ }^{33}$.

Sendo assim, estando o crime de branqueamento de capitais inserido em um contexto de criminalidade organizada internacional, é

29 FORTHAUSER apud BLANCO CORDERO, Isidoro. El delito de blanqueo de capitales. Navarra: Editorial Aranzadi, 2002. p. 52.

30 Tradução por BLANCO CORDERO, Isidoro. El delito de blanqueo de capitales. Navarra: Editorial Aranzadi, 2002. p. 57.

31 GRABER, Christoph K. Geldwäscherei: Ein Kommentar zu Art.305bis und 305ter StGB. Bern: Verlag Stämpfli \& Cie AG Bern, 1990. pp. 57-58 e BLANCO CORDERO, Isidoro. El delito de blanqueo de capitales. Navarra: Editorial Aranzadi, 2002. p. 57.

32 Ibidem. p. 58. Sobre o tema: CANESTRARO, Anna Carolina. Compartilhamento de dados e persecução do Crime de branqueamento de capitais no âmbito dos Paraísos financeiros. Revista de Estudos Jurídicos da UNESP, Franca, v. 22, n. 35, p. 135-143, 2018. https://doi.org/10.22171/rej.v22i35.2197

33 ASSUNÇÃO, Maria Leonor Machado Esteves Campos e. Medidas de combate aos paraísos fiscais numa economia globalizada subordinada ao dogma liberal: um paradoxo incurável? Revista do Ministério Público, n.120, p.101-144. out./dez. 2009. p.123. 
que se verifica crucial que os atos necessários à persecução também se configurem em contextos internacionais, ou seja, que não fiquem limitados às fronteiras de um único Estado ou território ${ }^{34}$, evitando assim que as fronteiras físicas ou jurídicas entre os Estados conduzam a uma situação de ineficácia dos mecanismos de persecução nacional frente a uma delinquência transnacional cada vez mais organizada ${ }^{35}$.

É nesse sentido, portanto, que se chega à conclusão de que os Estados precisam se ajudar em prol de um objetivo comum, isto é, a persecução dessa criminalidade transfronteiriça. E, deste modo, a Cooperação Jurídica Internacional se torna fundamental para ultrapassar essas barreiras e alcançar a efetivação da justiça penal. De fato, mais do que uma liberalidade de cada Estado, esta colaboração se torna uma necessidade, uma obrigação internacional ${ }^{36}$.

\section{DA COOPERAÇÃO JURÍDICA INTERNACIONAL}

E uma vez que a maior preocupação aqui é prevenir a reinserção e reutilização do dinheiro ilícito no financiamento de novas condutas delitivas, principalmente por organizações criminosas, não basta que se prendam seus autores, devendo-se, em verdade, possibilitar o rastreio do próprio dinheiro (follow the money). Desta feita, é de se dizer que o primeiro passo para uma política criminal mais eficiente na represália dessa nova criminalidade se sustenta em uma maior possibilidade de rastreamento dos bens que se originam dos atos infracionais ${ }^{37}$.

34 SOUZA, Carolina Yumi de. Cooperação jurídica internacional em matéria penal: considerações práticas. Revista Brasileira de Ciências Criminais, São Paulo, v. 16, n. 71, p. 297-325, mar./abr. 2008. p. 299

35 Assim: MONTALVO apud SALDANHA, Douglas Morgan Fullin. Cooperação jurídica internacional em matéria penal: das cartas rogatórias às equipes de investigação conjuntas. Segurança pública \& cidadania: revista brasileira de segurança pública e cidadania, Brasília, v. 4, n. 1, p. 115-137 jan./jun. 2011. p. 117.

36 SOUZA, Carolina Yumi de. Cooperação jurídica internacional em matéria penal: considerações práticas. Revista Brasileira de Ciências Criminais, São Paulo, v. 16, n. 71, p. 297-325, mar./abr. 2008. p. 300.

37 BADARÓ, Gustavo Henrique; BOTTINI, Pierpaolo Cruz. Lavagem de dinheiro: aspectos penais e processuais penais: comentários à Lei 9.613/1998, com as alteração da Lei 12.863/2012. São Paulo: Editora Revista dos Tribunais, 2016. p.30. 
No entanto, conforme já mencionado, o caráter internacional do crime de lavagem de dinheiro traz grande dificuldade para as políticas nacionais, e estas, aliadas à sofisticação das operações e de seus operadores, passam a não ser suficientes para combater essa criminalidade.

De tal modo, para que se possa realizar tal rastreio, verifica-se a necessidade de se desenvolver mecanismos a nível internacional, além de haver um esforço para uma mínima harmonização das legislações, buscando-se compatibilizar preceitos e, principalmente, facilitar comunicações, atos e diligências conjuntas para prevenir cada vez mais tais práticas delitivas $^{38}$.

\subsection{PreVisões Internacionals}

Tendo-se em vista que o Estado apenas possui jurisdição dentro de seu território, é essencial a cooperação sempre que houver necessidade da produção de uma medida extraterritorial para obter o necessário auxílio no sentido de se perseguir e prevenir delitos transfronteiriços, garantindo, assim, a eficácia da prestação jurisdicional ${ }^{39}$.

E a fim de facilitar essa cooperação, diversos tratados e convenções foram assinados no sentido de se trazer recomendações e mesmo estratégias para um melhor combate à esta criminalidade. E no que tange aos mecanismos de persecução no âmbito internacional, quando diante

38 No mesmo sentido: BOTTINI, Pierpaolo Cruz. Prevenção à lavagem de dinheiro: novas perspectivas sob o prisma da lei e da jurisprudência. Revista de Direito Bancário e do Mercado de Capitais, São Paulo, vol. 67, p. 163-195, jan./ mar., 2015.p.163. BADARÓ, Gustavo Henrique; BOTTINI, Pierpaolo Cruz. Lavagem de dinheiro: aspectos penais e processuais penais: comentários à Lei 9.613/1998, com as alteração da Lei 12.863/2012. São Paulo: Editora Revista dos Tribunais, 2016. p.31; CALLEGARI, André Luis; WEBER, Ariel Barazzetti. Lavagem de Dinheiro. São Paulo: Atlas, 2014. p. 49.

39 SOUZA, Carolina Yumi de. Cooperação jurídica internacional em matéria penal: considerações práticas. Revista Brasileira de Ciências Criminais, São Paulo, v. 16, n. 71, p. 297-325, mar./abr. 2008.p.300. Em sentido semelhante: SALDANHA, Douglas Morgan Fullin. Cooperação jurídica internacional em matéria penal: das cartas rogatórias às equipes de investigação conjuntas. Segurança pública \& cidadania: revista brasileira de segurança pública e cidadania, Brasília, v. 4, n. 1, p. 115-137, jan./jun. 2011. p. 117 
do crime de lavagem de dinheiro, fala-se muito a respeito da necessidade de medidas de prevenção.

De fato, é nesse sentido, inclusive, as orientações internacionais tanto do Comitê de Ministros Do Conselho da Europa (1980 $)^{40}$ como da Declaração de Princípios da Basileia $(1988)^{41}$ que, buscando proteger o sistema bancário ${ }^{42}$, traz recomendações - exclusivamente para esses sistemas, é verdade -, nas quais se acentua a importância de os bancos verificarem e conhecerem a identidade e costumes de seus clientes know your client ${ }^{43}$ - para justamente poderem constatar comportamentos

40 Recomendação do Comitê de Ministros do Conselho da Europa de $\mathrm{n}^{\circ} \mathrm{R}$ (80)10 relativa às medidas contra a transferência e ao encobrimento de capitais de origem criminosa. Apesar de não conter nenhuma disposição jurídico-penal, traz um padrão mínimo de medidas bancárias para combater o branqueamento de capitais (tendo-se aqui como referência os bancos, mas não aos profissionais que, com frequência são utilizados para lavar dinheiro, como administradores de bens ou assessores fiscais e financeiros). No entanto, por ser uma recomendação, não tem caráter vinculante, os postulados dessa iniciativa não terem alcançado o esperado reflexo nos ordenamentos estatais; assim, ABEL SOUTO, Miguel Ángel. Normativa internacional sobre el blanqueo de dinero y su recepción en el ordenamiento penal español. Tese (Doutorado em 2001) - Universidad de Santiago de Compostela, Santiago de Compostela, 2001. p. 69. Disponível em: <http://www.cervantesvirtual.com/nd/ ark:/59851/bmc0p0z9>. Acesso em: 26 de maio de 2017.

41 Aprovada em 1988 pelo Comitê de Regras e Práticas de Controle de Operações Bancárias com o objetivo de evitar as perdas de dinheiro em razão de fraudes e busca evitar uma publicidade negativa aos bancos. E segundo Abel Souto, a Declaração traz como regra primordial a preocupação em se conhecer e manter a identificação de seus clientes - No entanto, fala-se apenas em solicitar dados de novos clientes e não daqueles que já possuem contas anônimas no momento de transposição da Declaração. ABEL SOUTO, Miguel Ángel. Normativa internacional sobre el blanqueo de dinero y su recepción en el ordenamiento penal español. Tese (Doutorado em 2001) - Universidad de Santiago de Compostela, Santiago de Compostela, 2001. p. 58. Disponível em: <http://www.cervantesvirtual.com/nd/ark:/59851/bmc0p0z9>. Acesso em: 26 de maio de 2017.

42 Apesar de serem orientações voltadas exclusivamente ao sistema bancário, considera-se importante mencioná-las vez que representam um tímido começo de um forte empenho comunitário em tutelar preventivamente a transparência da atividade bancária já com a finalidade de combater a lavagem de produtos delitivos. Ibidem, p.50.

43 NETTO, Alamiro Velludo Salvador; COSTA, Helena Regina Lobo da. Lavagem de dinheiro: anteprojeto de Lei IBCCRIM. São Paulo: IBCCRIM - Instituto 
suspeitos de lavagem ainda no momento de colocação desses valores no sistema financeiro; isto é, antes que se tenha a dissimulação e ocultação desses proventos.

Na sequência, a Convenção das Nações Unidas de 88 (Convenção de Viena), que, apesar de vincular o crime de branqueamento de capitais estritamente com o tráfico de drogas, reafirma a responsabilidade coletiva de todos os Estados e ressalta a importância da Cooperação Internacional, reconhecendo, inclusive, a necessidade de se fortalecer e intensificar os meios jurídicos para a cooperação internacional em matéria penal ${ }^{44}$.

Ainda dentre as previsões internacionais destacam-se as orientações do Grupo de Ação Financeira (GAFI), criado em 1989 pelo então G7 com o objetivo de desenvolver e promover estratégias de luta contra a lavagem de dinheiro, se utilizando, para tanto, de suas recomendações ${ }^{45}$. Dentre elas, chama-se atenção para as de número 36 a 40, em que se ressalta a importância da Cooperação Judiciária e a necessidade de os países se tornarem signatários das convenções internacionais que

Brasileiro de Ciências Criminais, 2013. 2 v. (Seminário internacional do Instituto Brasileiro de Ciências Criminais, 19). Disponível em: <http://www. ibccrim.org.br/tvibccrim_video/243-Lavagem-de-dinheiro-anteprojeto-de -lei-IBCCRIM>. Acesso em: 1 de maio de 2017.

44 Preâmbulo da Convenção contra o tráfico ilícito de entorpecentes e de substâncias psicotrópicas Disponível em: <http://www.planalto.gov.br/ccivil_03/decreto/1990-1994/D0154.htm>. Acesso em 13 de junho de 2017.

45 Atualmente, o GAFI dispõe de 49 recomendações, sendo que as nove últimas dizem respeito ao terrorismo, destacando a importância que esse crime obteve desde o atentado nos Estados Unidos no ano de 2001. O GAFI conta com especialistas que efetuam uma fiscalização constante no sentido de se verificar se os países estão de fato seguindo suas recomendações (tanto no sentido de elaboração de leis como na sua prática) e, em seguida, são emitidos relatórios com novas recomendações sobre o que ainda deve ser feito para tornar o combate ao crime de branqueamento mais efetivo. Apesar de não ter caráter vinculante, como os relatórios vão para todas as instituições internacionais (ONU, Banco Mundial, União Europeia, por exemplo) acabam gerando reações econômicas e financeiras tais que criam uma grande pressão política para que os Estados as adotem. Inclusive, muitas foram as alterações legislativas realizadas a partir desses relatórios; a alteração da Lei de Lavagem de Dinheiro do Brasil em 2012, por exemplo, foi realizada justamente em vista às recomendações do GAFI do ano de 2010. Relatório de avaliação mútua do brasil do GAFI disponível em: <http://www.coaf.fazenda.gov.br/links-externos/Sumario\%20Executivo\%20 Brasil\%202010.pdf>. Acesso em: 13 de junho de 2017. 
tratem do crime de lavagem dinheiro e, também, que tomem medidas para que suas autoridades possam prestar cooperação de forma cada vez mais rápida e eficaz ${ }^{46}$.

É certa, portanto, a preocupação a nível internacional com relação ao combate desta nova e transfronteiriça criminalidade, e, dessa forma, verifica-se uma cada vez maior necessidade da existência de mecanismos judiciais que, de forma mais célere e eficaz, consigam auxiliar os Estados nesta complexa e dinâmica persecução.

\subsection{Mecanismos JudiciaIs de Cooperação}

No que tange aos mecanismos judiciais, isto é, como essa cooperação internacional poderá ser realizada na prática, o GAFI cita, em suas recomendações de ${ }^{\circ}$ s 37 e 39, os mecanismos de "auxílio mútuo" e "extradição", respectivamente ${ }^{47}$.

46 Não é objetivo, no presente estudo traçar características de cada uma das convenções internacionais a respeito do tema, e, por isso, optou-se por selecionar apenas as orientações mais importantes que auxiliaram na construção das conclusões do presente trabalho. Deste modo, apenas para que não se falte com a informação, o GAFI, em sua recomendação de $n^{\circ} 36$, menciona como principais convenções em matéria de branqueamento de capitais: Convenção de Viena (1988), Convenção de Palermo (2000), Convenção das Nações Unidas contra a Corrupção (2003) e Convênio Internacional para a Repressão do Financiamento do Terrorismo (1999), Convenção da Europa sobre Crimes Cibernéticos (2001), Convenção Interamericana contra o Terrorismo (2002) e Convênio do Conselho da Europa sobre Branqueamento, detecção, apreensão e perda dos produtos do crime e ao financiamento do terrorismo (2005). Disponível em < http://www.fatf-gafi.org/media/fatf/documents/recommendations/pdfs/FATF-40-Rec-2012-Portuguese-GAFISUD.pdf >. Acesso em: 13 de junho de 2017.

47 Apesar de haver outros mecanismos judiciais de cooperação, vide a Lei Portuguesa $n^{\circ} 144 / 99$ - que, em seu art. $2^{\circ}$, prevê, além da extradição e do auxílio judiciário mútuo em matéria penal, a transmissão de processos penais, a transferência de pessoas condenadas a penas e medidas de segurança privativas da liberdade, vigilância de pessoas condenadas ou libertadas condicionalmente -, tendo-se em vista que o GAFI se verifica como órgão especializado no combate ao crime de branqueamento de capitais e, em respeito ao recorte temático realizado nesse trabalho - que se atém à matéria de cooperação internacional em matéria de branqueamento de capitais - opta-se por aprofundar o presente estudo nos mecanismos apresentados pelo próprio GAFI. 
No que diz respeito ao auxílio ou assistência judiciária mútua, prevista na recomendação de ${ }^{\circ} 37$, tomando-se por referência a definição apresentada na Lei Portuguesa de Cooperação Judiciária Internacional em matéria penal de ${ }^{\circ}$ 144/99 (Art. 145º), tem-se que tal mecanismo "compreende a troca de comunicação de informações, de atos processuais e outros atos públicos admitidos pelo direito português, quando se afigurarem necessários à realização das finalidades do processo".

Assim, este seria o procedimento adequado para, segundo a mesma Lei (Art. $145^{\circ} \mathrm{n}^{\circ} 2$ ), um Estado (requerente) poder obter de outro Estado (requerido): notificação de atos e entrega de documentos; obtenção de meios de prova; revistas, buscas, apreensões, exames e perícias; notificação e audição de suspeitos, arguidos, testemunhas ou peritos; trânsito de pessoas, e; informações sobre o direito português ou estrangeiro e as relativas aos antecedentes penais de suspeitos, arguidos e condenados.

A extradição, por sua vez, pode ser entendida como um mecanismo de cooperação judiciária através do qual um Estado (requerente) solicita a outro Estado (requerido) ou jurisdição, a transferência de determinada pessoa que se encontra sob a sua autoridade, a fim de dar seguimento a um procedimento criminal ou para dar cumprimento de sentença condenatória ${ }^{48}$.

É de se chamar atenção, no entanto, para o fato de que a extradição encontra aqui uma especificidade, isto é, ao contrário do que ocorre com os sistemas de prestação de assistência jurídica mútua, a extradição possui como princípio norteador a dupla-incriminação ${ }^{49}$-inclusive, no caso do Brasil, quanto ao crime antecedente ${ }^{50}$ - fato este que poderia prejudicar a cooperação internacional no caso de o país requerido não tipificar as condutas fundantes do pedido de extradição.

48 FIGUEIREDO, José Miguel. A extradição activa na Lei de Cooperação Judiciária Internacional em Matéria Penal. In: CAEIRO, Pedro. Temas de Extradição e Entrega. Coimbra: Editora Almedina, 2015. p. 11-41. p.11-12.

De acordo com a Lei Brasileira de $\mathrm{n}^{\circ} 6.815$, que define a situação jurídica do estrangeiro no Brasil, em seu artigo 77, II: "Não se concederá a extradição quando: (...) II - o fato que motivar o pedido não for considerado crime no Brasil ou no Estado requerente".

50 Vide: BELOTTO, Ana Maria de Souza; MADRUGA, Antenor; TOSI, Mariana Tumbiolo. Dupla incriminação na cooperação jurídica internacional. Boletim IBCCRIM, São Paulo, v. 20, n. 237, p. 15-16., ago, 2012. p.15. 
Nesse sentido, o GAFI, em seu Relatório de Avaliação Mútua do Brasil referente ao ano de $2010^{51}$, chama a atenção justamente para essas deficiências da criminalização. E isto pois, apesar de suas orientações, não há, entre as legislações, uma total harmonização quanto às condutas a serem tipificadas como lavagem de dinheiro ${ }^{52}$.

Como resultado, ainda que relativamente firme quando na extradição - apesar de a jurisprudência vir caminhando no sentido de que não se exige uma perfeita identidade do nomem iuris, sendo, portanto, suficiente a subsunção das condutas ao tipo penal ${ }^{53}$ - a exigência da dupla-incriminação já vem sendo afastada em outras modalidades de cooperação penal, principalmente quando as diligências requeridas não têm caráter coercitivo ${ }^{54}$.

Definidos os dois métodos judiciais de cooperação expressamente trazidos pelas recomendações do GAFI ${ }^{55}$, verifica-se que ambos são de extrema importância para o combate à criminalidade; a extradição, para se possibilitar

51 Relatório de Avaliação Mútua do Brasil do GAFI - Prevenção à Lavagem de Dinheiro e Combate ao Financiamento do Terrorismo. Jun. 2010 p.4. Disponível em: <http://www.coaf.fazenda.gov.br/links-externos/Sumario\%20 Executivo\%20Brasil\%202010.pdf >. Acesso em: 13 de junho de 2017.

52 A exemplo disso, ao contrário do que se verifica em Portugal, o Brasil considera a "utilização", na atividade econômica ou financeira, dos bens, direitos ou valores provenientes de infração penal, como conduta criminosa. Semelhante polêmica se verifica nos casos de auto-branqueamento, aceito por alguns países e não por outros.

53 Nesse sentido: STF - Ext: 1413 DF - DISTRITO FEDERAL 0005701-28.2015. 1.00.0000, Relator: Min. LUIZ FUX, Data de Julgamento: 26/04/2016, Primeira Turma.

54 Nesse sentido: BELOTTO, Ana Maria de Souza; MADRUGA, Antenor; TOSI, Mariana Tumbiolo. Dupla incriminação na cooperação jurídica internacional. Boletim IBCCRIM, São Paulo, v. 20, n. 237, p. 15-16., ago, 2012. p.15.

55 Importante frisar aqui que estes não são os únicos métodos de cooperação. Em verdade, a título de curiosidade, dentro da União Europeia, por exemplo, um método que tem muito destaque é o denominado mandado de detenção europeu, mecanismo este que veio substituir os procedimentos de extradição entre os países da União Europeia, tornando assim o procedimento muito mais rápido e eficiente. Para um maior aprofundamento do tema, vide: CAEIRO, Pedro; FIDALGO, Sônia. "O mandado de detenção europeu na experiência portuguesa: tópicos da primeira década”. In: CAEIRO, Pedro (coord.). Temas de Extradição e Entrega. Coimbra: Almedina, 2015. p. 157-194 e JANUARIO, Túlio Felippe Xavier. Do princípio da proporcionalidade e sua aplicação no mandado de 
a persecução do Estado requerente com relação a uma determinada pessoa e o auxílio mútuo para permitir a troca de comunicação de informações, de atos processuais e outros atos públicos necessários ao processo.

No entanto, analisando-se ambos os mecanismos, verifica-se que ao menos no que tange à prevenção do específico crime de lavagem de dinheiro, o mecanismo de extradição encontra limitações, e isto porque, ao se "perseguir" o delinquente, olvida-se que este, na maior das vezes, não atua sozinho e, por certo, seria uma peça substituível na organização criminosa e, nesse sentido, a despeito da captura de um dos membros, a atividade delitiva poderia continuar a ser praticada.

Sendo assim, é justamente por esse sentido que se destaca a importância do auxílio mútuo entre os diferentes Estados. E isto pois, por meio da troca de informações entre as autoridades, viabiliza-se não só a persecução de um indivíduo singular, mas também a identificação dos outros integrantes da organização, permitindo-se, assim, que, de fato, se dissolva a organização criminosa e se iniba novas infrações.

Além disso, o auxílio mútuo também guarda grande importância ainda na fase da investigação. E isto porque, ao contrário do que ocorre com a extradição - que tem por objetivo o rastreio de uma pessoa física ao redor do globo - este mecanismo relaciona-se diretamente com o Sistema Financeiro, isto é, ele permite que se rastreie informações neste âmbito que é justamente o principal problema dessa criminalidade. Assim, ao invés de perseguir um dos agentes, o auxílio mútuo e essa troca de informações permite a realização do follow the money a partir dos rastros deixados pelos proventos ilícitos, permitindo, assim, o real confisco dessas vantagens anteriores.

Destarte, considerando-se as especificidades dessa nova criminalidade global, que se estrutura a partir, principalmente, de organizações criminosas, com avançada capacitação técnica e que se utiliza do mercado financeiro como palco para as suas condutas, verifica-se que o mecanismo de extradição não seria o meio mais adequado, uma vez que dificilmente acarretaria no encerramento das atividades ilícitas do grupo ou conseguiria o confisco dos valores obtidos indevidamente. 


\section{DA TRANSMISSÃo dO PEDIDO dE AUXíLIO MÚTUO}

Destacada, portanto, a importância do auxílio mútuo na persecução do crime de branqueamento de capitais, cumpre esclarecer, então, como se dá, processualmente, a transmissão e concretização desse pedido.

\subsection{Carta RogatóRIa}

Tradicionalmente, o auxílio mútuo é realizado mediante expedição de carta rogatória, isto é, por meio de um pedido formal de assistência feito por uma autoridade Judiciária de um Estado a outro; havendo, assim, a diferenciação entre cartas ativas, ou seja, quando uma autoridade solicita o auxílio da autoridade estrangeira para alcançar algum dos elementos necessários à persecução penal que se encontram fora de seu território nacional, e cartas passivas, quando a autoridade recebe o pedido de auxílio de outra autoridade estrangeira ${ }^{56}$.

No Brasil, as cartas rogatórias se verificam tuteladas tanto pelo Código de Processo Civil (dentre os quais se destacam os artigos 36 e 960 ao 965) como pelo Código de Processo Penal (artigos 780 ao 786) e, no caso do Processo Penal, as rogatórias ativas, conforme leitura do artigo 783 "serão, pelo respectivo juiz, remetidas ao Ministro da Justiça, a fim de ser pedido o seu cumprimento, por via diplomática, às autoridades estrangeiras competentes" ${ }^{57}$.

No entanto, o trâmite, por certo, estará de acordo com a legislação interna do país emitente da carta rogatória, como por exemplo, em Portugal, onde os pedidos devem ser dirigidos à Procuradoria Geral da República, que se encaminhará de enviá-los ao exterior ${ }^{58}$.

56 SOUZA, Carolina Yumi de. Cooperação jurídica internacional em matéria penal: considerações práticas. Revista Brasileira de Ciências Criminais, São Paulo, v. 16, n. 71, p. 297-325, mar./abr. 2008, p. 306 e 315.

57 BRASIL. Decreto-lei n. ${ }^{\circ}$ 3.689, de 3 de outubro de 1941: Código de Processo Penal. Disponível em: <http://www.planalto.gov.br/ccivil_03/decreto-lei/ Del3689Compilado.htm>. Acesso em: 21 de fevereiro de 2019.

58 Informações retiradas do Guia de Auxílio Judiciário Mútuo em Matéria Penal. Disponível em: < http://guiaajm.gddc.pt/emissao_pedido.html>. Acesso em: 29 de maio de 2017. 
Já no caso de carta rogatória passiva, no Brasil, os tribunais nacionais, ao receber o pedido, deverão conceder o exequatur, isto é, fazer uma análise formal de requisitos no sentido de se conferir a possibilidade de execução da cooperação em território nacional por meio de um juízo de delibação.

No caso do Brasil, a despeito do previsto anteriormente pelo Código de Processo Penal - que, em seu artigo 784, $\$ 1^{\circ}$ prevê a competência do Supremo Tribunal Federal - o exequatur pertence ao Superior Tribunal de Justiça e, em sendo assim, o pedido de cooperação, recebido por via diplomática, será, após o juízo de delibação, encaminhado ao juízo competente para a sua execução $0^{59}$.

Há de se falar, no entanto, que não está previsto na legislação brasileira qualquer prazo para o cumprimento da carta rogatória. De fato, o Art.786 do Código de Processo Penal Brasileiro apenas fala em "prazo razoável, que poderá ser excedido, havendo justa causa" ${ }^{60}$. E, diante deste cenário, afirma Damásio de Jesus ${ }^{61}$ que $70 \%$ das cartas rogatórias brasileiras não são cumpridas e, as que são, demoram, no mínimo dois anos; fazendo com que muitos processos sejam atingidos pela prescrição da pretensão punitiva do Estado ${ }^{62}$.

Também nesse sentido, o relatório do $\mathrm{GAFI}^{63}$ chama atenção para o fato de que a obtenção das cartas rogatórias pode ser muito demorada e

59 Nesse sentido: GOVERNO FEDERAL. MINISTÉRIO DA JUSTIÇA E SEGURANÇA PÚBLICA. Roteiro de Tramitação em matéria penal. Disponível em: <http://www.justica.gov.br/sua-protecao/cooperacao-internacional/cooperacao-juridica-internacional-em-materia-penal/roteiro-de-tramitacao>. Acesso em 12 de março de 2019.

60 BRASIL. Decreto-lei n. ${ }^{o} 3.689$, de 3 de outubro de 1941: Código de Processo Penal. Disponível em: <http://www.planalto.gov.br/ccivil_03/decreto-lei/ Del3689Compilado.htm>. Acesso em: 21 de fevereiro de 2019.

${ }^{61}$ JESUS, Damásio Evangelista de. Prescrição penal e rogatória não cumprida. Revista Síntese de direito penal e processual penal, Porto Alegre, v. 4, n. 24, p.5-6 fev./mar. 2004, p.5.

62 Uma vez ser certo que, conforme o parágrafo único do Artigo 222-A, a expedição de carta rogatória não suspende a instrução criminal. BRASIL. Decreto -lei n. ${ }^{\circ}$ 3.689, de 3 de outubro de 1941: Código de Processo Penal. Disponível em: <http://www.planalto.gov.br/ccivil_03/decreto-lei/Del3689Compilado.htm>. Acesso em: 21 de fevereiro de 2019.

63 Relatório de Avaliação Mútua do Brasil do GAFI - Prevenção à Lavagem de Dinheiro e Combate ao Financiamento do Terrorismo. Jun. 2010 p.4. 
que, em não havendo informação sobre o tempo necessário para responder aos pedidos de assistência mútua em geral, haveria uma preocupação quanto à capacidade do Brasil em prestar uma efetiva cooperaçã $0^{64}$.

Como resultado, tendo-se em vista a demora no alcance da cooperação por meio de carta rogatória, e buscando-se uma forma mais rápida e eficiente - seguindo as expressas orientações do GAFI e das convenções internacionais ${ }^{65}$ - verifica-se que, cada vez mais, vem se defendendo e se justificando que se tenha, como regra, um mecanismo de transmissão direta.

\subsection{Auxílıo Direto}

O auxílio direto representa um procedimento destinado ao intercâmbio entre órgãos judiciais e administrativos de Estados diversos independentemente de carta rogatória, isto é, de forma direta entre as próprias autoridades interessadas ${ }^{66}$. Ou seja, ao invés de se utilizar da via diplomática, o auxílio direto se utiliza da figura da denominada " $\mathrm{Au}$ toridade Central" ${ }^{67}$, que, no Brasil, a principal seria o Departamento de

Disponível em: <http://www.coaf.fazenda.gov.br/links-externos/Sumario\%20Executivo\%20Brasil\%202010.pdf >. Acesso em: 13 de junho de 2017.

64 No mesmo sentido, o GAFI afirma que também nos casos de extradição "não há medidas em vigor para assegurar que os pedidos e os procedimentos de extradição relacionados à lavagem de dinheiro sejam tratados sem demora”.

65 Neste sentido: art. $27^{\circ}, 2$ da Convenção das Nações Unidas contra o Crime Organizado Transnacional, art. $10^{\circ}, 1$ e 2 da Convenção contra o Tráfico Ilícito de Entorpecentes e Substâncias Psicotrópicas, art. 46º 13 da Convenção das Nações Unidas contra a Corrupção e o art. $3^{\circ}, 1$ do Protocolo de Assistência Jurídica Mútua em Assuntos Penais (Mercosul). À nível Europeu, se verificam, os arts. $21^{\circ} n^{\circ} 4$ e $152^{\circ} n^{\circ} 1$ da Lei Portuguesa $n^{\circ} 144 / 99$, o art. $53^{\circ}$ da Convenção de Aplicação do Acordo de Schengen - CAAS e os arts. $3^{\circ}$ e $6^{\circ}$ da Convenção Europeia de Auxílio Judiciário Mútuo no âmbito dos Estados da União Europeia, de 29 de maio de 2000.

66 SILVA apud. SALDANHA, Douglas Morgan Fullin. Cooperação jurídica internacional em matéria penal: das cartas rogatórias às equipes de investigação conjuntas. Segurança pública \& cidadania: revista brasileira de segurança pública e cidadania, Brasília, v. 4, n. 1, p. 128.

67 "A definição sobre quem poderá ser considerado como autoridade requerente vem contida nas disposições do tratado ou nas leis que regem a matéria. Normalmente, 
Recuperação de Ativos e Cooperação Jurídica Internacional - DRCI ${ }^{68}$, e, em Portugal, a Procuradoria Geral da República, por competência delegada do Ministério da Fazenda.

Esta autoridade ficará responsável por receber, analisar, adequar, transmitir e acompanhar o cumprimento dos pedidos de cooperação judiciária, além de analisar os requisitos da lei do estado requerido, e, principalmente, garantir a celeridade e eficácia do pedido ${ }^{69}$.

Em sendo assim, na medida em que possibilita a troca de informações entre autoridades de diferentes Estados sem que seja necessária a via diplomática - e, na grande maioria das vezes, sem que seja necessário o exequatur -, esse mecanismo permite que se alcance a cooperação de forma mais célere ${ }^{70}$ e, por isso, seria um mecanismo mais efetivo de cooperação.

De fato, segundo busca realizada junto ao sistema do Superior Tribunal de Justiça brasileiro, a partir das palavras-chave "carta rogatória" e"lavagem de dinheiro" e "cooperação internacional" verificou-se que, no espaço temporal de 01.01.2000 a 20.05.2019, apenas foi protocolada uma

são as autoridades judiciais e os membros do Ministério Público. Em alguns casos, são admitidas a autoridade policial e outras administrativas com atribuição de aplicação de sanção, como a Receita Federal", nesse sentido: SOUZA, Carolina Yumi de. Cooperação jurídica internacional em matéria penal: considerações práticas. Revista Brasileira de Ciências Criminais, São Paulo, v. 16, n. 71, p. 297-325, mar./abr. 2008, p.321.

68 Fala-se aqui em principal porque existem convenções que definem outras autoridades centrais, tais como a Secretaria Especial de Direitos Humanos (no caso da Convenção de Haia sobre Cooperação Internacional e Proteção de Crianças e Adolescentes em Matéria de Adoção Internacional), a Procuradoria Geral da República (conforme a Convenção de Nova Iorque sobre Prestação de Alimentos no Estrangeiro, o Tratado de Auxílio Mútuo em Matéria Penal entre Brasil e Portugal e o Tratado de Assistência Mútua em Matéria Penal entre Brasil em Canadá).

69 Nesse sentido: MINISTÉRIO DA JUSTIÇA; SECRETARIA NACIONAL DE JUSTIÇA; DEPARTAMENTO DE RECUPERAÇÃO DE ATIVOS E COOPERAÇÃO JURÍDICA INTERNACIONAL. Cartilha de Cooperação Jurídica Internacional em Matéria Penal. Ano 2012. p.9. Disponível em <http://www.justica. gov.br/sua-protecao/lavagem-de-dinheiro/institucional-2/publicacoes/arquivos/cartilha-penal-09-10-14-1.pdf>. Acesso em: 15 de junho de 2017.

70 Nesse sentido: SANTOS, Laura Rodrigues dos. Cooperação Jurídica Internacional Em Matéria Criminal: Das Rogatórias Ao Auxílio Direto. Disponível em: <http://www3.pucrs.br/pucrs/files/uni/poa/direito/graduacao/tcc/tcc2/ trabalhos2012_2/laura_santos.pdf>. Acesso em: 13 de junho de 2017. 
carta rogatória ( $\mathrm{CR} \mathrm{n}^{\circ}$ 438/BE), autuada em 31/01/2005 e com registro de "saída para Ministério das Relações Exteriores" em 12/08/2010, ou seja, mais de 5 anos, quase 66 meses $^{71}$. Suprimindo o termo "lavagem de dinheiro" e mantendo-se o espaço temporal de 01.01 .2000 a 20.05 .2019 verifica-se a existência de mais 16 cartas rogatórias ${ }^{72}$ autuadas entre o mesmo período, demorando em média 34,4 meses desde a data de atuação e a remessa de saída.

No entanto, de acordo com dados obtidos diretamente com o Departamento de Recuperação de Ativos e Cooperação Jurídica Internacional - DRCI, desde o ano de 2014 (lembrando que a pesquisa junto ao STJ considerou como prazo inicial o ano 2000) até o maio/2017 teriam sido tramitados 370 pedidos de Cooperação Internacional envolvendo o crime de lavagem de dinheiro - porcentagem essa que representaria $47 \%$ do total de pedidos protocolados neste período com relação às demais matérias - demorando um tempo médio de 12 meses $^{73}$, ou seja, quase um terço do tempo que se levaria com o pedido por carta rogatória.

71 SUPERIOR TRIBUNAL DE JUSTIÇA. CR 438/BE, Rel. Ministro Luiz Fux, Corte Especial, julgado em 15/08/2007, DJ 24/09/2007, p. 224. Disponível em: $<$ https://ww2.stj.jus.br/processo/pesquisa/?src=1.1.3\&aplicacao=processos.ea\&tipoPesquisa=tipoPesquisaGenerica\&num_registro=200500151960>. Acesso em: 21 de maio de 2019.

72 São elas: CR n ${ }^{0}$ 998/IT (autuada em 19/07/2005 e registro de saída para o Ministério da Justiça em 16/10/2012); CR no 9923/DE (autuada em 15/04/2015 e registro saída em 11/01/2018); CR 11165/US (autuada em 13/09/2016 e encaminhada para Coordenadoria de Recursos Extraordinários em 26/06/2018); CR n ${ }^{0}$ 9952/ES (autuada em 28/04/2015 e registro de saída em 01/02/2017); CR n ${ }^{\circ}$ 9824/ES (autuada em 23/02/2015 e registro de saída em 19/09/2016); CR n ${ }^{\circ}$ 9832/ BO (autuada em 26/02/2015 e remessa de saída em 03/10/2016); CR n ${ }^{\circ}$ 9854/ FR (autuada em 17/03/2015 e remessa em 08/03/2016); CR no 9563/CN (autuada em 14/10/2014 e saída para arquivamento em 18/04/2018); CR no 8145/IL (autuada em 24/05/2013 e saída para remessa em 03/10/2014); CR n ${ }^{\circ} 8436 / \mathrm{PT}$ (autuada em 14/08/2013 e remessa em 13/11/2014); CR n ${ }^{\circ}$ 7350/PT (autuada em 26/10/2012 e remessa em 02/03/2017); CR no 7961/PT (autuada em 18/03/2013 e remessa em 02/12/2013); CR no 5694/ PT (autuado em 17/03/2011 e saída em 02/08/2018); CR n ${ }^{\circ} 4037 / \mathrm{CH}$ (autuada em 07/05/2009 e entrada na coordenadoria de Recursos Extraordinários em 07/10/2015); CR n 6692/ PT (autuada em 13/04/2012 e remessa em 22/11/2012); CR n ${ }^{\circ} 5238 / P T$ (autuada em 31/08/2010 e remessa em 17/08/2012).

73 Dados obtidos diretamente (via e-mail) com o DRCI por meio das informações prestadas pela Coordenadora de Recuperação de Ativos Luíza Rocha Jacobsen. 
E um dos motivos que justificariam essa maior celeridade é que esse mecanismo tem por base, primordialmente, os Acordos Internacionais (Bilaterais, Multilaterais ou Regionais) firmados entre os Estados para pré-estabelecer as regras para cooperação. Esses acordos, denominados Mutual Legal Assistance Treaties (MLATs) ${ }^{74}$, são acordos celebrados entre os governos e buscam facilitar o intercâmbio de informações relevantes para uma investigação que esteja em andamento em pelo menos um dos Estados ${ }^{75}$.

Assim, essa cooperação embasada em tratados, além de facilitar a cooperação, na medida em que pré-determina as regras a serem seguidas, traz maior certeza ao processo e permite uma comunicação mais fluida entre as diferentes autoridades ${ }^{76}$.

Ademais, os acordos são também muito importantes no que tange à soberania dos Estados; e isto pois, quando na cooperação internacional, não pode o Estado requerente impor que o Estado requerido cumpra

74 Vale dizer que o auxílio direto entre os membros da União Europeia segue uma outra dinâmica, isto é, de acordo com a Convenção Europeia de Auxílio Judiciário Mútuo no âmbito dos Estados da União Europeia. Assim, no contexto da União Europeia, a transmissão direta, ou auxílio direto, já é uma regra. Deste modo, rege-se o reconhecimento e confiança mútua, e, em sendo assim, a transmissão de pedidos, de forma sucinta, é feita diretamente entre autoridades judiciárias localmente competentes (sendo estas identificadas pelo Atlas Judiciário disponibilizado pela Rede Judiciária Europeia). Nesse sentido: MINISTÉRIO PÚBLICO DE PORTUGAL. COOPERAÇÃO JUDICIÁRIA INTERNACIONAL EM MATÉRIA PENAL. Disponível em: < http://www.ministeriopublico.pt/pagina/ cooperacao-judiciaria-internacional-em-materia-penal>. Acesso em: 12 de junho de 2017.

75 VILARES, Fernanda Regina. Medidas assecuratórias na lei de lavagem. São Paulo: IBCCRIM - Instituto Brasileiro de Ciências Criminais, 2014. (VIII Curso de Pós-graduação em Direito Penal Econômico). Disponível em: <http:// www.ibccrim.org.br/tvibccrim_video/185-Medidas-Assecuratorias-na-leide-lavagem>. Acesso em: 1 de maio de 2017; sobre o tema: CANESTRARO, Anna Carolina. Compartilhamento de dados e persecução do Crime de branqueamento de capitais no âmbito dos Paraísos financeiros. Revista de Estudos Jurídicos da UNESP, Franca, v. 22, n. 35, p. 135-143, 2018. https://doi. org/10.22171/rej.v22i35.2197

76 Assim, SOUZA, Carolina Yumi de. Cooperação jurídica internacional em matéria penal: considerações práticas. Revista Brasileira de Ciências Criminais, São Paulo, v. 16, n. 71, p. 297-325, mar./abr. 2008, p. 313. 
a medida extraterritorial conforme a sua legislação ${ }^{77}$; agora, diante da existência de acordos, podem os Estados prever dispositivos específicos a serem aplicados no âmbito do tratado ${ }^{78}$ e que estejam em concordância com a sua legislação. Além disso, há de se falar que os Estados, ao terem certa liberalidade para estipularem as regras, podem fazê-lo de acordo com as necessidades e especificidades de suas relações com cada Estado, podendo modificá-la de acordo com o momento penal ${ }^{79}$.

Também por via dos tratados e acordos internacionais e comunicação direta entre as autoridades, interessante citar, que se verificam as chamadas equipes de investigação conjunta, isto é, equipes que subsistem por tempo determinado com um objetivo específico de efetuar investigações criminais em um ou em vários dos Estados-Membros ${ }^{80}$.

77 Nesse sentido, chama-se a atenção para o caso UBS x IRS, de 2008, no qual os Estados Unidos buscaram a cooperação internacional do Banco Suíço UBS para conseguir dados bancários de clientes americanos suspeitos que poderiam estar se utilizando no banco suíço para fraudar o imposto de renda. Importante dizer que, nesse caso, o impasse apenas pôde ser resolvido quando os países decidiram celebrar um acordo, ao que, segundo os dizeres de Eveline Widmer-Schlumpf, então Ministra da Justiça Suíça: "Com esse acordo, nós conseguimos evitar um conflito entre a soberania de dois Estados". Artigo disponível em: <http://economia.estadao.com.br/noticias/geral,suica-anuncia-acordo-com-eua-sobre-dados-de-clientes-do-ubs,421358>. Acesso em: 15 de junho de 2017.

78 Como é o caso, por exemplo, do Código de Processo Penal Brasileiro que, em seu artigo $1^{\circ}$, prevê "O processo penal reger-se-á, em todo território brasileiro, por esse Código, ressalvados: I- os tratados, as convenções e regras de direito internacional".

79 "Diversamente do que acontece com outras formas de cooperação internacional, o conteúdo do auxílio judiciário define-se através de uma fórmula aberta, susceptível de evoluir de acordo com as circunstâncias de tempo e lugar, decorrentes do grau de desenvolvimento das relações entre os Estados implicados, das possibilidades de cooperação reconhecidas pela legislação interna de cada Estado e da evolução das necessidades de cooperação internacional, em função da evolução do próprio fenômeno da criminalidade”; assim: MARQUES apud SOUZA, Carolina Yumi de. Cooperação jurídica internacional em matéria penal: considerações práticas. Revista Brasileira de Ciências Criminais, São Paulo, v. 16, n. 71, p. 297-325, mar./abr. 2008, p.320.

80 "As autoridades competentes de dois ou mais Estados-Membros podem criar, de comum acordo, uma equipa de investigação conjunta para um objectivo específico e por um período limitado, que poderá ser prolongado com o 
Permitindo assim a união das autoridades com capacidade operacional em territórios distintos e possibilitando a troca de informações e experiências das forças policiais ${ }^{81}{ }^{82}$.

No caso, todavia, de inexistir Tratado previamente celebrado entre os Estados, a cooperação por meio do auxílio direto ainda poderá ser realizada, mas será ela fundamentada na garantia de reciprocidade; isto é, baseada no compromisso assumido pelo Estado requerente no sentido de que, nas mesmas circunstâncias, cumprirá medidas equivalentes àquelas executadas pelo Estado requerido ${ }^{83}$. No entanto, enquanto que a cooperação via tratados facilita a cooperação, vez que delimita as regras a serem seguidas e traz maior celeridade e segurança ao processo, a cooperação via promessa de reciprocidade tem a desvantagem de depender, quase que exclusivamente de o Estado requerido aceitar ou não os termos da promessa, fator esse que dificulta o andamento e o entendimento da cooperação vez que a execução da cooperação está atrelada a outro ordenamento jurídico.

acordo de todas as partes, para efectuar investigações criminais num ou em vários dos Estados-Membros que criarem a equipa. A composição da equipa será indicada no acordo", EUR-LEX. Auxílio judiciário mútuo em matéria penal entre os Estados-Membros da União Europeia. Disponível em: <https://eur-lex. europa.eu/legal-content/PT/TXT/?uri=LEGISSUM\%3Al33108>. Acesso em: 13 de março de 2019.

81 MONTALVO apud SALDANHA, Douglas Morgan Fullin. Cooperação jurídica internacional em matéria penal: das cartas rogatórias às equipes de investigação conjuntas. Segurança pública \& cidadania: revista brasileira de segurança pública e cidadania, Brasília, v. 4, n. 1, p. 115-137 jan./jun, 2011. p. 131.

82 E, vale dizer, cada vez mais vem se destacando a importância da criação dessas equipes de investigação para o combate à essa nova criminalidade - não só com relação aos crimes de branqueamento de capitais, mas aos crimes internacionais graves em geral. Nesse sentido, apenas à título exemplificativo, recentemente foi aprovada no Brasil a Lei de $n^{\circ} 13.344$ de 06 de outubro de 2016, que dispõe justamente a respeito da necessidade de sua criação quando no crime de tráfico internacional de pessoas.

83 Inclusive, vale ressaltar, os Tratados poderão prever expressamente a desnecessidade daquela dupla-incriminação anteriormente citada como uma trava para o mecanismo de extradição, como é o caso do acordo bilateral celebrado entre Brasil e Espanha; vide: BELOTTO, Ana Maria de Souza; MADRUGA, Antenor; TOSI, Mariana Tumbiolo. Dupla incriminação na cooperação jurídica internacional. Boletim IBCCRIM, São Paulo, v. 20, n. 237, p. 15-16, ago, 2012. p.15. 
Feitas estas considerações, defende-se então que a cooperação internacional mediante o auxílio direto, principalmente por via dos tratados internacionais ${ }^{84}$, permite uma cooperação muito mais dinâmica, célere e de acordo comas soberanias e as garantias processuais (uma vez que estas também se verificam nos termos dos tratados, garantindo assim maior segurança ao processo $)^{85}$. Ademais, ao trazer maior celeridade, tem-se, por consequência, uma maior eficiência da cooperação, e isto pois, por se tratar de bens ilícitos que se pretendem integrar ao mercado, quanto antes for prestada a cooperação, menor a chance de confusão, integração e perda dos valores ilícitos.

\section{Grupo Egmont e Unidades de Inteligência Financeira}

Por fim, para que se tenha um eficaz combate à essa complexa criminalidade, destaca-se que não se deve pensar tão somente em um contexto de persecução, mas sim na junção dos mecanismos de persecução - já mencionados - com os de prevenção.

Desta feita, no sentido de se dar orientações e maior suporte para que o próprio Sistema Financeiro tenha meios de se resguardar dessas condutas criminosas, interessante chamar atenção para o denominado Grupo Egmont. Isto é, um organismo internacional informal sui generis, criado por iniciativa da Unidade Financeira de Inteligência Belga (CTIF) e norte-americana (FINCEN) para promover, em nível mundial, a troca de informações sobre o sistema financeiro, além de receber as comunicações, por parte dos organismos financeiros, sobre suspeitas

84 De fato, a importância e as orientações para que fossem firmados tratados internacionais no sentido da cooperação internacional já se verificam desde a Convenção de Viena (88), que, em seu art. $5^{\circ}, 2^{\circ}$, que, ao falar do confisco dos produtos derivados do delito, afirma: "g) As Partes procurarão negociar tratados, acordos ou entendimentos bilaterais ou multilaterais para reforçar a eficiência da cooperação internacional prevista neste Artigo".

85 SOUZA, Carolina Yumi de. Cooperação jurídica internacional em matéria penal: considerações práticas. Revista Brasileira de Ciências Criminais, São Paulo, v. 16, n. 71, p. 297-325, mar./abr. 2008. p.323. 
relacionadas à lavagem de dinheiro visando, justamente, estimular a cooperação internacional ${ }^{86}$.

Para fazer essa troca de informações à nível global, o Grupo reúne as chamadas Unidades de Inteligência Financeira, criadas em vários países (atualmente já se tem mais de 100 UIFs) que se encontram regularmente para buscar formas de cooperar entre si, especialmente nas áreas de intercâmbio de informações, treinamento e troca de experiências sobre as mais novas condutas de branqueamento verificadas no mercado financeiro.

No âmbito do Grupo Egmont, os trabalhos estão voltados para três principais áreas: assuntos legais, tecnologia/treinamento e assistência à criação de novas unidades. Assim, o objetivo é promover um ambiente no qual as Unidades Inteligência Financeira possam, em conjunto entre si e com o Sistema Financeiro, encontrar melhores soluções para ampliar os respectivos programas nacionais de combate à lavagem de dinheiro ${ }^{87}$.

Deste modo, a principal função da UIF $^{88}$ (que pode ter natureza judicial, policial, mista ou administrativa ${ }^{89}$ ) é estabelecer um mecanismo de prevenção e controle do crime de lavagem de dinheiro por meio da proteção dos setores financeiros e comerciais a partir de um maior intercâmbio de informações financeiras, devendo coordenar e propor mecanismos de cooperação e de troca de informações que viabilizem ações rápidas e eficientes no combate à ocultação ou dissimulação de proventos ilícitos.

86 CONSELHO DE CONTROLE DE ATIVIDADES FINANCEIRAS DO MINISTÉRIO DA FAZENDA - COAF. Cartilha - Lavagem de dinheiro - Um problema mundial. Setembro de 2015. Disponível em: <http://www.coaf.fazenda.gov.br/ $\mathrm{menu} / \mathrm{pld}-\mathrm{ft} / \mathrm{publicacoes} /$ cartilha.pdf/view>. Acesso em: 01 de maio de 2017. CONSELHO DE CONTROLE DE ATIVIDADES FINANCEIRAS DO MINISTÉRIO DA FAZENDA - COAF. Cartilha - Lavagem de dinheiro - Um problema mundial. Setembro de 2015. Disponível em: <http://www.coaf.fazenda. gov.br/menu/pld-ft/publicacoes/cartilha.pdf/view>. Acesso em: 01 de maio de 2017. no Plano de Ação Contra Lavagem de Dinheiro (adotados na Sessão Especial da Assembleia Geral das Nações Unidas sobre o Problema Mundial das Drogas, 1998, Nova Iorque). Idem.

No caso do Brasil, o COAF (Conselho de Controle de Atividades Financeiras) tem natureza administrativa e, no caso de Portugal, de acordo com a Lei Portuguesa de $n^{0} 37 / 2008$ (atualizada em 2016) a UIF segue o modelo policial judiciário. 
E dentro das competências do Grupo, está a de receber (e requerer informações de órgãos Administrativos), analisar e distribuir às autoridades competentes as denúncias sobre as informações financeiras com respeito a procedimentos suspeitos e presumidamente criminosos conforme legislação ou normas nacionais para, justamente, impedir a concretização do crime de lavagem ${ }^{90}$.

Nesse sentido, resumidamente, as Unidades de Inteligência recebem (ou pedem) esclarecimentos provenientes de órgãos ou entidades e de pessoas obrigadas a prestar informações ${ }^{91}$ e na sequência, encaminham essas informações para outras Unidades (podendo, inclusive, apontar ou indicar rumos para as investigações) e para as autoridades policiais e judiciais. Uma vez recebidas essas informações, as autoridades policiais e judiciais devem dar início aos procedimentos cabíveis para se dar continuidade à investigação.

De grande importância, portanto, para o combate ao crime financeiro o inter-relacionamento entre as unidades de inteligência e as autoridades competentes de cada país, na medida em que as unidades, por serem mais especificas, possuem maior conhecimento, melhores técnicas (programas) e ao se comunicarem entre si, conseguem ter um acesso mais rápido às informações e, ao repassá-las às autoridades centrais, permitem um combate mais eficaz à essa complexa criminalidade.

\section{Considerações Finais}

Pelo exposto, verifica-se que o crime de lavagem de dinheiro se processa em um âmbito de uma nova criminalidade econômica surgida a partir, principalmente, de um maior fluxo de informações/capital e cada

90 CONSELHO DE CONTROLE DE ATIVIDADES FINANCEIRAS DO MINISTÉRIO DA FAZENDA - COAF. Cartilha - Lavagem de dinheiro - Um problema mundial. Setembro de 2015. Disponível em: <http://www.coaf.fazenda. gov.br/menu/pld-ft/publicacoes/cartilha.pdf/view $>$. Acesso em: $01 \mathrm{de}$ maio de 2017.

91 É o dever de comunicação que se impõe a determinados agentes econômicos e grupos profissionais em razão, principalmente, de sua maior exposição - é o caso, por exemplo, do gerente do Banco que tem uma fundada suspeita da natureza ilícita da operação). 
vez menor controle sobre as movimentações financeiras. E, em sendo assim - e tamanha as proporções alcançadas com essa criminalidade - há de se questionar se haveria algum mecanismo à disposição do Estado que o permitiria realizar com mais eficiência e rapidez o necessário follow the money típico dessa específica criminalidade.

Nesse sentido, a resposta que aqui se destaca é que, por ser esta uma criminalidade complexa e, principalmente, transfronteiriça, mister se faz a cooperação a nível internacional entre os países, isto é, para que se permita a troca de informações entre Estados e sistemas financeiros diversos a fim de se detectar o quanto antes essas condutas de dissimulação, evitando-se que sejam pulverizadas e fundidas à proventos lícitos.

Com relação ao método de transmissão do pedido de cooperação, uma vez que o crime de lavagem de dinheiro tem em seus agentes pessoas com avançado conhecimento sobre o sistema financeiro e que têm a possibilidade de efetuar complexas transações em tempo instantâneo, mister se faz um método de transmissão que preze pela celeridade e eficiência. Desta feita, dentre os mecanismos judiciais de cooperação previstos pelo Grupo de Ação Financeira, destaca-se o auxílio direto, pois, ao contrário dos outros mecanismos - que apenas excluem um elemento fungível de uma organização grande e complexa -, este permite que se obtenha informações mais céleres e provenientes do próprio sistema financeiro; devendo esse auxílio ser fundamentado, por certo, em Tratados Internacionais por questões de respeito às garantias processuais e à soberania dos Estados.

Também ganham papel de destaque no combate à lavagem os mecanismos de prevenção, aqui citadas as Unidades de Inteligência Financeira - UIFs, que, a partir de um compartilhamento de informações e de experiências anteriores, permitem que os países possam evoluir, modernizar e se especializar cada vez mais no combate à essa criminalidade.

Sendo assim, diante de todo o exposto, percebe-se que a Cooperação Internacional tem grande importância no combate aos crimes econômicos e, em especial, no combate ao crime de lavagem de dinheiro; sendo o auxílio direto, aliado aos mecanismos de prevenção uma importante medida não apenas de repressão dos infratores, mas também de investigação e prevenção dessa importante forma de criminalidade global. 


\section{ReferênCiAs}

ABEL SOUTO, Miguel Ángel. Normativa internacional sobre el blanqueo de dinero y su recepción en el ordenamiento penal español. Tese (Doutorado em 2001) - Universidad de Santiago de Compostela, Santiago de Compostela, 2001. Disponível em: <http://www.cervantesvirtual.com/nd/ark:/59851/bmc0p0z9>. Acesso em: 26 de maio de 2017.

ASSUNÇÃO, Maria Leonor Machado Esteves Campos e. Medidas de combate aos paraísos fiscais numa economia globalizada subordinada ao dogma liberal: um paradoxo incurável? Revista do Ministério Público, n. 120, p.101-144. out./dez. 2009.

BADARÓ, Gustavo Henrique; BOTTINI, Pierpaolo Cruz. Lavagem de dinheiro: aspectos penais e processuais penais: comentários à Lei 9.613/1998, com a alteração da Lei 12.863/2012. São Paulo: Editora Revista dos Tribunais, 2016.

BELOTTO, Ana Maria de Souza; MADRUGA, Antenor; TOSI, Mariana Tumbiolo. Dupla incriminação na cooperação jurídica internacional. Boletim IBCCRIM, São Paulo, v. 20, n. 237, p. 15-16., ago, 2012.

BITENCOURT, Cezar Roberto; MONTEIRO, Luciana de Oliveira. Lavagem de dinheiro segundo a legislação atual. Revista Brasileira de Ciências Criminais, São Paulo, v. 21, n. 102, p. 163-220, mai./jun, 2013.

BLANCO CORDERO, Isidoro. El delito de blanqueo de capitales. Navarra: Editorial Aranzadi, 2002.

BOTTINI, Pierpaolo Cruz. Prevenção à lavagem de dinheiro: novas perspectivas sob o prisma da lei e da jurisprudência. Revista de Direito Bancário e do Mercado de Capitais, São Paulo, vol. 67, p. 163-195, jan./mar, 2015.

CAEIRO, Pedro. A decisão-quadro do conselho, de 26 de Junho de 2001, e a relação entre a punição do branqueamento e o facto precedente: necessidade e oportunidade de uma reforma legislativa. In: ANDRADE, Manuel da Costa; COSTA, José de Faria; RODRIGUES, Anabela Miranda; ANTUNES, Maria João (eds.). Liber Discipulorum para Jorge de Figueiredo Dias. Coimbra: Coimbra Editora, 2003. p. 1067-1132.

CAEIRO, Pedro; FIDALGO, Sônia. "O mandado de detenção europeu na experiência portuguesa: tópicos da primeira década”. In: CAEIRO, Pedro (coord.). Temas de Extradição e Entrega. Coimbra: Almedina, 2015. p. 157-194.

CANESTRARO, Anna Carolina. Compartilhamento de dados e persecução do Crime de branqueamento de capitais no âmbito dos Paraísos financeiros. Revista 
de Estudos Jurídicos da UNESP, Franca, v. 22, n. 35, p. 135-143, 2018. https://doi. org/10.22171/rej.v22i35.2197.

CASO UBS x IRS. Análise disponível em: <http://economia.estadao.com.br/noticias/geral,suica-anuncia-acordo-com-eua-sobre-dados-de-clientes-do-ubs,421358>. Acesso em: 15 de junho de 2017.

CONSELHO DE CONTROLE DE ATIVIDADES FINANCEIRAS DO MINISTÉRIO DA FAZENDA - COAF. Cartilha - Lavagem de dinheiro - Um problema mundial. Setembro de 2015. Disponível em: <http://www.coaf.fazenda.gov.br/menu/pld-ft/ publicacoes/cartilha.pdf/view>. Acesso em: 01 de maio de 2017.

EUR-LEX. Auxílio judiciário mútuo em matéria penal entre os Estados-Membros da União Europeia. Disponível em: < https://eur-lex.europa.eu/legal-content/PT/ TXT/?uri=LEGISSUM\%3Al33108>. Acesso em: 13 de março de 2019.

FATF-GAFI. Le blanchiment de capitaux: qu'est-ce que c'est? - Comment blanchit-on des capitaux?. Disponível em: <http://www.fatf-gafi.org/fr/foireauxquestionsfaq/ blanchimentdecapitaux/>. Acesso em: 29 de agosto de 2018.

FIGUEIREDO, José Miguel. A extradição activa na Lei de Cooperação Judiciária Internacional em Matéria Penal. In: CAEIRO, Pedro. Temas de Extradição e Entrega. Coimbra: Editora Almedina, 2015. p. 11-41.

GIACOMOLLI, Nereu José; SANTOS, Laura Rodrigues dos. Cooperação jurídica internacional em matéria criminal: autoridades centrais, das rogatórias ao auxílio direto. Revista de Estudos Criminais, Porto Alegre, v. 10, n. 46, p. 97-116, jul./ set. 2012.

GOVERNO FEDERAL. MINISTÉRIO DA JUSTIÇA E SEGURANÇA PÚBLICA. Roteiro de Tramitação em matéria penal. Disponível em: <http://www.justica. gov.br/sua-protecao/cooperacao-internacional/cooperacao-juridica-internacional-em-materia-penal/roteiro-de-tramitacao>. Acesso em 12 de março de 2019.

GRABER, Christoph K. Geldwäscherei: Ein Kommentar zu Art.305bis und 305ter StGB. Bern: Verlag Stämpfli \& Cie AG Bern, 1990.

GUIA DE AUXÍLIO JUDICIÁRIO MÚTUO EM MATÉRIA PENAL. Disponível em: < http://guiaajm.gddc.pt/emissao_pedido.html>. Acesso em: 29 de maio de 17.

JANUARIO, Túlio Felippe Xavier. Do princípio da proporcionalidade e sua aplicação no mandado de detenção europeu. Revista Brasileira de Direito Processual Penal, Porto Alegre, vol.4, n.1, p.435-472, jan./abr, 2018. https://doi.org/10.22197/ rbdpp.v4i1.114. 
JESUS, Damásio Evangelista de. Prescrição penal e rogatória não cumprida. Revista Síntese de direito penal e processual penal, Porto Alegre, v. 4, n. 24, p. 5-6, fev./mar. 2004.

LAMPE, Ernst- Joachim. El nuevo tipo penal del blanqueo de dinero ( $\$ 261$ StGB), Tradução de Miguel Abel Souto. Estudios Penales y Criminológicos, nº XX, 1997. p.118, nota 24 .

MACHADO, Leonardo Marcondes. A lavagem de dinheiro no Brasil: breves apontamentos sobre as gerações legislativas. Revista Síntese de Direito Penal e Processual Penal (continuação da Revista IOB de Direito Penal e Processual Penal),v.15, n. 90, p.34-43, fev./mar. 2015. p.37. Disponível em <https://bdjur. tjdft.jus.br/xmlui/handle/tjdft/27671>. Acesso em 26 de maio de 17.

MAIA, Rodolfo Tigre. Lavagem de Dinheiro (Lavagem de ativos provenientes de crime) - anotações às disposições criminais da Lei n.9.613/98. São Paulo: Malheiros Editores, 2004. pp.37-38.

MINISTÉRIO DA JUSTIÇA; SECRETARIA NACIONAL DE JUSTIÇA; DEPARTAMENTO DE RECUPERAÇÃO DE ATIVOS E COOPERAÇÃO JURÍDICA INTERNACIONAL. Cartilha de Cooperação Jurídica Internacional em Matéria Penal. Ano 2012. p.9. Disponível em < http://www.justica.gov.br/sua-protecao/lavagem-dedinheiro/institucional-2/publicacoes/arquivos/cartilha-penal-09-10-14-1.pdf >. Acesso em: 15 de junho de 2017.

MINISTÉRIO PÚBLICO DE PORTUGAL. COOPERAÇÃO JUDICIÁRIA INTERNACIONAL EM MATÉRIA PENAL. Disponível em: < http://www.ministeriopublico. $\mathrm{pt} /$ pagina/cooperacao-judiciaria-internacional-em-materia-penal>. Acesso em: 12 de junho de 2017.

NETTO, Alamiro Velludo Salvador; COSTA, Helena Regina Lobo da. Lavagem de dinheiro: anteprojeto de Lei IBCCRIM. São Paulo: IBCCRIM - Instituto Brasileiro de Ciências Criminais, 2013. 2 v. (Seminário internacional do Instituto Brasileiro de Ciências Criminais, 19). Disponível em: <http://www.ibccrim.org.br/tvibccrim_video/243-Lavagem-de-dinheiro-anteprojeto-de-lei-IBCCRIM>. Acesso em: 1 de maio de 2017 .

NIETO MARTÍN, Adán. La responsabilidad penal de las personas jurídicas: esquema de un modelo de responsabilidad penal. Nueva Doctrina Penal, Buenos Aires, A, p. 125-159, 2008.

PRADO, Luiz Regis. O novo tratamento penal da lavagem de Dinheiro (Lei 12.683/2012). Revista dos Tribunais Online, v. 101, n. 926, p. 401- 436, dez/2012. 
RELARÓRIO DE AVALIAÇÃO MÚTUA DO BRASIL DO GAFI - SUMÁRIO EXECUTIVO. Disponível em:<<http://www.coaf.fazenda.gov.br/links-externos/ Sumario\%20Executivo\%20Brasil\%202010.pdf>. Acesso em: 13 de junho de 17.

RODRIGUES, Anabela Maria Pinto Miranda. Lavagem de capitais. São Paulo: IBCCRIM - Instituto Brasileiro de Ciências Criminais, 2014. (VIII Curso de Pós-graduação em Direito Penal Econômico). Disponível em: <http://www. ibccrim.org.br/tvibccrim_video/155-Lavagem-de-capitais $>$. Acesso em: 1 de maio de 2017.

RODRIGUES, Anabela Maria Pinto Miranda. O direito penal europeu emergente. Coimbra: Coimbra Editora, 2008.

RODRIGUES, Anabela Miranda. Globalização, Democracia e Crime. In: COSTA, José de Faria; SILVA, Marco Antonio Marques da. Direito penal especial, processo penal e direitos fundamentais: visão luso-brasileira. São Paulo: Quartier Latin do Brasil, 2006. p. 277- 310.

SALDANHA, Douglas Morgan Fullin. Cooperação jurídica internacional em matéria penal: das cartas rogatórias às equipes de investigação conjuntas. Segurança pública \& cidadania: revista brasileira de segurança pública e cidadania, Brasília, v. 4, n. 1, p. 115-137. jan./jun, 2011.

SANTOS, Laura Rodrigues dos. Cooperação Jurídica Internacional Em Matéria Criminal: Das Rogatórias Ao Auxílio Direto. Disponível em: <http://www3.pucrs.br/ pucrs/files/uni/poa/direito/graduacao/tcc/tcc2/trabalhos2012_2/laura_santos. pdf>. Acesso em: 13 de junho de 2017.

SAVONA, Ernesto. Mafia money-laundering versus Italian legislation. European Journal on Criminal Policy and Research, v. 1-3, pp.31-56, 1993. https://doi. org/10.1007/BF02249506.

SILVA SANCHEZ, Jesús-María. La Expanción del Derecho Penal: aspectos de la política criminal em las sociedades postindustriales. Madrid: Civitas Ediciones, 2001.

SIMÕES, Euclides Dâmaso. A importância da cooperação judiciária internacional no combate ao branqueamento de capitais. Revista Portuguesa de Ciência Criminal, Coimbra, v. 16, n. 3, p. 423-474, jul./set. 2006.

SOUZA, Carolina Yumi de. Cooperação jurídica internacional em matéria penal: considerações práticas. Revista Brasileira de Ciências Criminais, São Paulo, v. 16, n. 71, p. 297-325, mar./abr. 2008. 
VILARES, Fernanda Regina. Medidas assecuratórias na lei de lavagem. São Paulo: IBCCRIM - Instituto Brasileiro de Ciências Criminais, 2014. (VIII Curso de Pós-graduação em Direito Penal Econômico). Disponível em: <http://www. ibccrim.org.br/tvibccrim_video/185-Medidas-Assecuratorias-na-lei-de-lavagem>. Acesso em: 1 de maio de 2017.

\section{Informações adicionais e declarações dos autores (integridade científica)}

Declaração de conflito de interesses (conflict of interest declaration): a autora confirma que não há conflitos de interesse na realização das pesquisas expostas e na redação deste artigo.

Declaração de autoria e especificação das contribuições (declaration of authorship): todas e somente as pessoas que atendem os requisitos de autoria deste artigo estão listadas como autores; todos os coautores se responsabilizam integralmente por este trabalho em sua totalidade.

Declaração de ineditismo e originalidade (declaration of originality): a autora assegura que o texto aqui publicado não foi divulgado anteriormente em outro meio e que futura republicação somente se realizará com a indicação expressa da referência desta publicação original; também atesta que não há plágio de terceiros ou autoplágio. 
Dados do processo editorial

(http://www.ibraspp.com.br/revista/index.php/RBDPP/about/editorialPolicies)

- Recebido em: 25/03/2019

Equipe editorial envolvida

- Controle preliminar e verificação de plágio: 11/04/2019

- Avaliação 1: 17/04/2019

- Avaliação 2: 23/04/2019

- Editor-chefe: 1 (VGV)

- Editor-associado: 1 (PC)

- Revisores: 2

- Decisão editorial preliminar: 12/05/2019

- Retorno rodada de correções: 22/05/2019

- Decisão editorial final: 28/05/2019

\section{COMO CITAR ESTE ARTIGO:}

CANESTRARO, Anna Carolina. Cooperação internacional em matéria de lavagem de dinheiro: da importância do auxílio direto, dos tratados internacionais e os mecanismos de prevenção. Revista Brasileira de Direito Processual Penal, Porto Alegre, vol. 5, n. 2, p. 623-658, mai./ago. 2019. https://doi.org/10.22197/rbdpp.v5i2.234

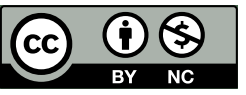

Esta obra está licenciada com uma Licença Creative Commons Atribuição-NãoComercial 4.0 Internacional. 